\title{
The Legal Fiction of a Genuine Link \\ AS A REQUIREMENT FOR THE GRANT OF \\ Nationality to Ships and Humans - THE \\ Triumph OF Formality OVER SUBSTANCE?
}

\author{
Gotthard Mark Gauci \& Kevin Aquilina \\ Plymouth University, United Kingdom \\ Faculty of Laws, University of Malta \\ gotthard.gauci@plymouth.ac.uk \\ kevin.aquilina@um.edu.mt
}

GAUCI, Gotthard Mark; AQUILINA, Kevin. The Legal Fiction of a Genuine Link as a Requirement for the Grant of Nationality to Ships and Humans - the Triumph of Formality over Substance? International and Comparative Law Review, 2017, vol. 17, no. 1, pp. 167-191. DOI 10.2478/iclr-2018-0007.

\begin{abstract}
Summary: This paper discusses nationality of a person, whether physical or legal, and compares and contrasts the international legal regime which regulates the nationality of both persons. Whilst humans are granted nationality because they are citizens of a state to which they owe allegiance, in the case of a res which enjoy nationality - such as a ship - the relationship between such a res and its national state is based on a functional dimension. A ship oftentimes navigates in areas beyond state jurisdiction (such as on the high seas) ending up in a legal vacuum if she enjoys no nationality to regulate its behaviour and whatever happens on board that ship during its extra-territorial voyages. The authors thus discuss the juridical nature of nationality, nationality of a res and of humans, and reflect upon the recent sale by states of their nationality to noncitizens thereby shifting human nationality closer to the commodification of nationality of which ships are a traditional instance. It concludes that nationality of ships and of humans has in some legal systems moved away from the classical International Court of Justice's Nottebohm case requirement of a pre-existing genuine link to one where nationality is reduced to a commodity.
\end{abstract}

Keywords: Legal fiction, genuine link, nationality, nationality of ships, nationality of humans, commodification of nationality, Nottebohm case

\section{Introduction}

This paper compares and contrasts the nationality of a persona in the strict sense of the word - of a human being - with the legal fiction sense of the term of an inanimate thing, a (res). It attempts to answer the question: how does the law regulate and distinguish human beings, on the one hand, and res enjoying nationality, on the other, and whether both these persons - natural (or physical) and legal (or fictitious) - are treated in the same manner or otherwise in so far as 
nationality law is concerned? It observes that whilst in public international law both a human and a ship are (i) considered objects of the law, (ii) afforded legal personality and, (iii) exceptionally in the case of those res which enjoy nationality, these two categories of persons are afforded a nationality. Although similarities exist between humans and the said res, it is clear that the legal regime regulating nationality does have its nuances when it deals with two types of persons.

To answer the question which it posits, this paper is divided into three parts: in the first part, very briefly, it sets out the juridical nature of nationality distinguishing it from other legal institutes such as registration and legal personality. In the second part, nationality of a res is discussed, albeit restrictively in so far as a ship is allowed by the international community of states to partake of nationality. The third part considers nationality rules which are pertinent to animate persons whilst the conclusion draws comparisons, contrasts and parallels between both nationality of an animate and an inanimate person. It concludes that in the case of a ship, by its own very nature she is a creature of the law, being more the product of commercial maritime law, whose mind and will is dominated by a human being, for a ship is owned and managed/operated by a human or by a body corporate (itself owned and managed by a human being), whilst in the case of animate persons their nationality derives more from their loyalty to the state of their nationality. On the other hand, recourse to the commodification of nationality, in so far as animate persons are concerned, is more the exception rather than the rule as there can be said to be no widespread consistent and uniform state practice which can be quoted in support of the crystallisation of an emerging norm of customary international law to this effect. In the case of humans, nationality is dictated more by security and social interests than by a functional consideration as in the case of a res enjoying a fictional personhood and partaking of the legal regime of nationality.

\section{The Juridical Nature of Nationality}

The law protects, recognizes and ascribes duties and rights not only to humans but also to other inanimate things. Yet the latter cannot be considered to be at a par with a natural person. For instance, certain laws protect human beings prior to birth. Such is the case with domestic violence where an unborn child in the mother's womb is afforded protection from a violent spouse or partner. Yet there are certain situations where a physical person is granted at law certain rights and duties which an inanimate thing cannot enjoy. The right to education, to vote at elections or referenda, or to express freely oneself are rights specifically reserved only to the human species. Yet again there are situations where a res is granted rights akin to a human being but which other inanimate objects do not enjoy. Such is the case with the right of arrest which, though it extends to a person and to a ship, ${ }^{1}$ it does not cover a company, foundation or other res. A

1 Aircraft are another res enjoying nationality. See Convention on International Civil Avia- 
contrariu sensu, there are other situations regulated by law where enforcement action can be taken against a res but not against a physical person. Take the case of a sale by auction of a ship. In the case of humans, slavery has been outlawed by international human rights law even though in the past this institute was regulated and allowed by law as in the case of Roman Law. Although both humans and ships can be classified under the heading of 'person' - whether physical in the former case or legal in the latter case - those res which are ascribed legal personality remain in an inferior and subordinate status to that of a natural person in so far as it is the latter who enjoy the jus utendi, jus fruendi et jus abutendi of the ship, not vice-versa. A human being can own, enjoy the fruits of, dispose of, destroy and exercise other acts of dominium over a res enjoying nationality which the latter can never do in relation to a physical person. Indeed, it is a human being who represents the will of the res enjoying nationality as, although the latter enjoys legal personality in its own right, distinct and separate from animate persons, it has no will of its own, in the sense that it is a human being who guides, operates and manages its actions and omissions. It is in this limited respect that such a res does not enjoy the full legal capacity of a human being.

Subjects of international law - primarily states - enjoy both rights and obligations. However, objects of international law other than human beings, such as ships, aircraft and spacecraft, are dispensed by specific provision of law from carrying out all the duties which a human being might be requested by law to perform. Yet not all subjects of the law are treated equally. For instance, within the human class there are situations where by law a male can marry at sixteen years of age and a female at fourteen. In so far as ships are concerned, a small ship need not be registered in a merchant shipping registry while a larger one must, de rigueur, be so registered, apart from being requested to comply with several applicable international conventions. Hence even amongst objects of international law inter se, whether animate or inanimate, the law affords them a different treatment.

Three key terms need to be discussed in relation to objects of international law. These are: nationality, registration and legal personality. In the case of humans, nationality is quite straight forward. A human being owes allegiance to the state of which $\mathrm{s} / \mathrm{he}$ is national, and this rule applies even in cases of dual or multiple nationality. This means that the state has certain rights and obligations vis-a-vis its citizens and vice-versa. There is therefore a bond between the state and its nationals. Nationality of a human being is ascertained in several ways. This can be acquired through birth, marriage, purchase, etc. In the case of a res enjoying nationality, like that of a ship, it is ascertained normally through registration. Needless to say, laws related to ship registration vary from one jurisdiction to another and so do the requirements and conditions for registration. Thus nationality and registration are not coterminous. This is because registration can

tion, art. 17, Dec. 7, 1944, 15 U.N.T.S. 295. 
be considered to be a connecting factor between the res (the ship in question) and its nationality. Registration of a ship is very much similar to the registration of a birth certificate of a human being in his or her state of birth registry. It is therefore a means of proving that a ship has been 'born' when it has been registered in a merchant shipping registry. The same applies to when a physical person dies and a ship is deregistered. Registration also demonstrates the genuine link between the ship and the state in which it is registered. The documentation in the case of a ship would be the certificate of registration in terms of the applicable Merchant Shipping statute. In the case of a physical person, the documentation would be the official act of civil status related to his or her birth (or death) - the birth (or death) certificate issued by the competent authority of the applicable state. Nigel P. Ready is of the view that: 'Registration means the entering of a matter in the public records. Registration is generally - but not always - not only a precondition for, but also the test of, a vessel's nationality.' He further opines that the 'public law functions of registration' include:

- the allocation of a vessel to a specific state and its subjection to a single jurisdiction for the purposes, for example, of safety regulations, crewing, and discipline on board;

- the conferment of the right to fly the national flag;

- the right to diplomatic protection and consular assistance by the flag state;

- the right to naval protection by the flag State;

- the right to engage in certain activities within the territorial waters of the flag State - for example, coastal fishing or trading between the ports of the flag State (cabotage);

- in the case of war, for determining the application of the rules of war and neutrality to a vessel. ${ }^{3}$

Registration in the case of a ship can be treated as equivalent to birth in the case of a human being. Whilst in the case of the latter birth is one of the criteria upon which nationality is conferred, there are other criteria in lieu of birth which, if satisfied, are nationality ascribing such as through marriage, purchase or residence for a specified period of time, say five years. But in the case of a ship, nationality can be acquired mainly, though not exclusively as in the case of a bareboat charter, through registration.

A physical person can enjoy nationality, domicile and residence but this is not the case of a ship which enjoys only nationality. A ship may be owned by a physical person who has a distinct and separate nationality of his/her own or by a

2 READY, Nigel. P. Nationality, Registration and Ownership of Ships. In FITZMAURICE, Malgosia, MARTÍNEZ GUTIÉRREZ, Norman, ARROYO, Ignacio, and BELJA, Elda (eds). The IMLI Manual of International Maritime Law, Volume 2: Shipping Law. Oxford: Oxford University Press, 2016, p. 25.

3 Ibid., p. 25. 
non-physical legal person such as a company which, though incorporated under the laws of a sovereign state, is not endowed with a nationality even though the company might be trading overseas. The requirement to ascribe nationality to a ship is considered to be a functional one because 'the high seas are not subject to the jurisdiction of any State. If, then, public order is to be preserved on the high seas, the right to navigate there must be restricted to those vessels which, through their link with a subject of international law, are subjected to its jurisdiction and can thus be required to comply with the network of customary and conventional rules which make up the public order of the oceans. ${ }^{3}$ It is clear from this passage that ships, nationality serves a particular intended function. This is evident through the way the genuine link of a ship to the flag state is incorporated in the United Nations Convention on the Law of the Sea 1982 (UNCLOS). Ships enjoy nationality simply for jurisdiction and enforcement purposes. For instance, when, on the high seas, they have to be regulated by law and whatever happens there on board that ship has to be regulated by international law. Otherwise, anarchy would prevail. The best solution devised by the human species so far over time is to afford, by way of a legal fiction, a nationality to a ship so that its acts and omissions, and whatever happens on board that ship whilst on the high seas, is regulated by law. This is the reason why, therefore, nationality of a ship has a functional character. If nationality is not granted to a ship on the high seas it will end up immune from legal process, lawless and stateless. As an antecedent to UNCLOS, in the Nottebohm case, ${ }^{5}$ the International Court of Justice ruled that 'the nationality of an individual presupposed the existence of a substantive connection between the individual and the State whose nationality he claimed.6

Nationality of ships is referred to in several provisions of UNCLOS, notably articles 29,91(1) and (2), 104, 106, and 110(1)(d) and (e). Of particular relevance is article 91(1) which, inter alia, allows Contracting Parties to grant their nationality to ships provided that there 'must exist a genuine link between the State and the ship'. However, UNCLOS does not define what constitutes a 'genuine link' or how can it be determined. The Convention then regulates the consequences of granting such nationality, as follows:

- the ship has to abide by 'the conditions for the grant of its nationality to ships' which conditions are laid down by the State Party' (Article 91(1))

- the flag state has the right to regulate the conditions 'for the registration of ships in its territory' (Article 91(1))

- the flag state can further impose those conditions it deems fit upon a ship to be able to enjoy 'the right to fly its flag' (Article 91(1))

4 BROWN, Edward D. The International Law of the Sea, Volume 1: Introductory Manual. Aldershot: Dartmouth Publishing Company Limited, 1994, p. 287.

5 Nottebohm Case (Liech. v. Guat.) (second phase), Judgment of April 6th, 1955: ICJ Reports 1955 p. 4.

6 READY, supra note 2 , at 30. 
- the flag state which has granted nationality to a ship 'shall issue to ships to which it has granted the right to fly its flag documents to that effect' (Article 91(2))

- a ship retains 'its nationality although it has become a pirate ship (Article 104)

- 'retention or loss of nationality is determined by the law of the State from which such nationality was derived' (Article 104)

- the state which has wrongfully seized a ship on suspicion of piracy is liable to 'the State the nationality of which is possessed by the ship ... for any loss or damage caused by the seizure' (Article 106)

- a warship may exercise its right of visit if it is suspected that 'the ship is without nationality' (Article 110(1)(d))

- a warship may also exercise its right of visit where 'though flying a foreign flag or refusing to show its flag, the ship is, in reality, of the same nationality of the warship' (Article 110(1)(e))

- a warship has to bear 'the external marks distinguishing such ships of its nationality' (Article 29).

Nationality has to be distinguished not only from registration but also from legal personality. Nationals - whether animate or inanimate - are endowed with legal personality but even corporate bodies established by or under a law enjoy such an attribute even if they are nationals of a state. Whilst local councils in Malta are established by the Local Councils Act ${ }^{7}$ and are all listed in a Schedule to that law, companies are established under the Maltese Companies Act ${ }^{8}$ but are not so listed in the law. Yet both Maltese local councils ${ }^{9}$ and companies ${ }^{10}$ enjoy legal personality. Physical persons, due to their inherent ontological nature are persons in their own right but the law does extend personhood to other inanimate objects of the law. A ship is an instance of a res which has legal personality bestowed upon it by law and not because personhood inheres therein.

\subsection{Nationality of a Res}

\subsubsection{Quasi-personification of ships}

Ships and humans are both endowed with nationality as distinct from mere legal personality. In the case of ships and aircraft international conventions specifically refer to nationality, whereas Article II of the Convention on Registration of Objects Launched into Outer Space 1975 refers to registration and does not make any reference to nationality. ${ }^{11}$ The personification theory in relation

7 Chapter 363 of the Laws of Malta.

8 Chapter 386 of the Laws of Malta.

9 Local Councils Act, $\$ 3(2)$.

10 Companies Act, $\$ 4(4)$.

11 United Nations Convention on the Law of the Sea (UNCLOS), art. 91, Dec. 10 $0^{\text {th }}, 1982833$ U.N.T.S. 3; Convention on International Civil Aviation (Chicago Convention), art. 17, Dec. 
to ships has long been espoused as one possible source relating to the origin of maritime liens and the in rem procedure in Admiralty Law. ${ }^{12} \mathrm{~A}$ ship can be viewed as an extension of the land territory of the flag state, ${ }^{13}$ although this 'floating territory,' ${ }^{14}$ or 'ambulatory province ${ }^{15}$ theory is subject to doubts and some obvious limitations. ${ }^{16}$

\subsubsection{Registration of Ships}

Nationality of a ship as distinct from nationality of its owner has been said to have emerged as a matter of State practice at the commencement of the nineteenth century. ${ }^{17}$ Registration of a ship is necessary as a matter of practice because a vessel or its owner may need the assistance or intervention of the flag state ${ }^{18}$ particularly when the ship is operating beyond the remit of the flag state's territorial jurisdiction, ${ }^{19}$ and also because an unregistered ship is likely to encounter problems similar to those that would be encountered by a stateless citizen ${ }^{20}$ and in terms of customary international law would be 'subject to the jurisdiction of

$7^{\text {th }}$, 1944, 15 U.N.T.S. 295; Convention on Registration of Objects Launched into Outer Space, art. II, Jan. 14th, 19751023 U.N.T.S. 15.

12 See PRICE, Griffith. The Law of Maritime Liens. London: Sweet \& Maxwell, 1940, pp. 5-6, where reference is made to writings by Judge Holmes; SCHOENBAUM, Thomas J. Admiralty and Maritime Law. St. Paul, Minn.: West Group, 2001, §7.1; The Comandante, (2008) 1 Lloyd’s Rep. 119, at \$103-107; and Senior Courts Act, 1981, c. 54, \$21(3) (U.K.).

13 See The Angel Bell [1979] 2 Lloyd's Rep. 491, per Donaldson J. It is notable that the Italian Navigation Code codifies the principle that an Italian-flagged vessel on the high seas constitutes Italian territory. The PRELIMINARY PROVISIONS OF THE SHORT CODE OF NAVIGATION, para. 4 (2002) states that: 'Le navi italiane in alto mare ... sono considerati come territorio italiano.' (Translation: Italian ships on the high seas ... are considered part of the Italian territory).

14 See COLES, Richard M.F., And WATT, Edward. Ship Registration: Law and Practice. London: Informa, 2009, at $\$ 1.22$.

15 Ibid.

16 See MEYERS, Herman. The Nationality of Ships. Den Haag: Martinus Nijhoff, 1967, at p. 13 et seq.

17 See COGLIATI-BANTZ, Vincent P. Means of Transportation and Registration of Nationality. Abingdon, Oxon.; New York, NY: Routledge, 2015, p. 17.

18 See Arctic Sunrise (Kingdom of the Netherlands v. Russian Federation) ITLOS, Nov. 22, 2013.

19 COGLIATI-BANTZ, supra note 17 , at 17 where it is stated that ' $[\mathrm{t}]$ he foundation of the concept of nationality was to ensure good order in international spaces, an order guaranteed by States, and the benefits of that order would be enjoyed by individuals through States.'

20 See The Asya [1948] AC 351 at 369 where the Judicial Committee of the Privy Council (on appeal from the Supreme Court of Palestine) acknowledged that on the high seas a vessel without registration was severely handicapped in international law: 'For the freedom of the open sea, whatever those words may connote, is a freedom of ships which fly, and are entitled to fly, the flag of a State which is within the comity of nations. The Asya did not satisfy these elementary conditions. No question of comity nor of any breach of international law can arise if there is no State under whose flag the vessel sails' (per Lord Simonds). 
all States ${ }^{21}$ Another important reason however why ships and aircraft require nationality, unlike other items without nationality e.g. cars or trucks, ${ }^{22}$ which do not, as a matter of routine, operate outside areas of national jurisdiction, is that nationality determines the applicable criminal law in areas beyond national jurisdiction. Furthermore, the availability of lending facility may depend on registration of the asset in a registry with sufficient legal protection for a lending institution registered as a mortgagee. In the case of ships it would appear that the main peace-time attraction of a flag state is the imposition of low tonnage tax by that state, and in times of conflict the principal attraction is the availability of the protection afforded to the registered ship by the naval forces of the flag state or its status as a neutral vessel. The view that a vessel can have a nationality without being registered is supported by the provisions of the very first section, specifically 1(1)(c), of the UK Merchant Shipping Act $1995 .{ }^{23}$

\subsubsection{Commercialisation of Nationality/Registration}

Nationality has been commercialised for a very long time in the case of ships and this coincides with the emergence of flags of convenience and off-shore registry systems, ${ }^{24}$ Although a ship's nationality may be ascertainable in the absence of registration, ${ }^{25}$ there are obvious benefits accompanying registration. It would appear that registration of ships emerged at the time of the Roman Empire, and harks back to 1660 in England. ${ }^{26}$ The second sentence in Article 91 of UNCLOS, provides that 'ships have the nationality of the State whose flag they are entitled to fly. ${ }^{27}$ Although the current ship registration in flag of convenience systems

21 COGLIATI-BANTZ, supra note 17, p. 19.

22 Ibid., p. 49.

23 Section 1 of the Merchant Shipping Act, 1995, c. 21 (U.K.) states that:

'(1) A ship is a British ship if-

(a) the ship is registered in the United Kingdom under Part II; or

(b) the ship is, as a Government ship, registered in the United Kingdom in pursuance of an Order in Council under section 308; or

(c) the ship is registered under the law of a relevant British possession; or

(d) the ship is a small ship other than a fishing vessel and-

(i) is not registered under Part II, but

(ii) is wholly owned by qualified owners, and

(iii) is not registered under the law of a country outside the United Kingdom.' (emphasis added).

24 See MANDARAKA-SHEPPARD, Aleka. Modern Maritime Law and Risk Management. London: Routledge-Cavendish, 2007, second edition, p. 278.

25 See COLES et al, supra note 14 , at $\$ 1.8$.

26 Ibid., at $\$ 1.6$.

27 See also Convention on the High Seas, art 5, Apr. 29, 1958, 450 U.N.T.S. 82. In relation to nationality of aircraft, see the Convention on International Civil Aviation, art. 17, supra note 9, which provides that: 'Aircraft have the nationality of the State in which they are registered'. Although there are differences between flags of convenience in shipping and the maritime industries (ODUNTAN, Gbenga. Sovereignty and Jurisdiction in the Airspace and Outer Space. London: Routledge, 2012, p. 8), one cannot help but notice that the Chi- 
has been broadly criticised as conducive to unideal shipping practices leading to problems with safety at sea and crew welfare, the regime is still widely available and there is stiff competition for business between the various open-registries. The weaknesses in the flag-state regulatory regime are in part addressed by systems of port-state control, by the role played by classification societies, and by contractual requirements in marine insurance contracts, relating to classification or nationality. ${ }^{28}$ The existence of the need and effectiveness of port-state control is a strong indictment of the flag of convenience system which claims as its raison dêtre the flag-state's control over the registered vessel. Moreover, in a fashion similar to, but clearly distinct from, dual citizenship, parallel registration of ships is readily available in some legal systems through the system of bareboat charter registration. ${ }^{29}$ Dual, as distinct from parallel, nationality of a ship would render a ship effectively stateless vis-à-vis other states. ${ }^{30}$ Furthermore besides the possibility of different categories of registration within one system (e.g. small ship's register, fishing vessel registration), some legal systems offer more than one system of registration via a second register as in the case of Norway ${ }^{31}$ or an offshore register; ${ }^{32}$ this latter phenomenon has been described as the response of traditional maritime state's to the unlikelihood of any attempt to abolish flags of convenience. $^{33}$

cago Convention on International Civil Aviation of 1944 does not contain the unequivocal pre-registration 'genuine link' stipulation provided for in the Convention Relating to the Regulation of Aerial Navigation, art. 7, Oct. 13, 1919, 11 L.N.T.S. 173: 'No aircraft shall be entered on the register of one of the contracting States unless it belongs wholly to nationals of such State. No incorporated company can be registered as the owner of an aircraft unless it possess the nationality of the State in which the aircraft is registered, unless the president or chairman of the company and at least two-thirds of the directors possess such nationality, and unless the company fulfils all other conditions which may be prescribed by the laws of the said State.'

28 See, for instance, International Hull Clauses (Nov., 1 2003), clauses 13 and 14.

29 See, e.g., the UK Merchant Shipping, Registration of Ships Regulations 1993 (S.I. 1993/3138) which provide for bareboat chartering-in of a vessel whose ownership remains registered in another jurisdiction. The parallel nature of bareboat charter registration is evident from the provisions of section 17 of the UK Merchant Shipping Act, 1995, c. 21 (U.K.) whereby a vessel bareboat chartered into the British ship registration system is entitled to fly the British maritime flag: the Merchant Shipping Act, 1995, c. 21 (U.K.) will broadly apply to such a ship as it does to other British-registered vessels; however in terms of section 17, private law matters are referred to the law of the country of the underlying (ownership) registry. For details relating to bareboat charter registration in general, see COLES et al, supra note 14, Chapter 4.

30 See UNCLOS, supra, art. 92.

31 See, e.g., the Act of 12 June 1987 No. 48 (Nor.) relating to a Norwegian International Ship Register (NIS).

32 See, COLES et al, supra note 14 , at $\$ 3.10$ and $\$ 3.39$ to $\$ 3.49$.

33 Ibid., at $\$ 3.39$. 


\subsubsection{The Genuine Link Quandary}

The reluctance to create a system where there is a proper link between the ship and the flag state is evident from the fact that the United Nations Convention on Conditions for the Registration of Ships $1986^{34}$ is still not in force; that Convention refers to the strengthening of a genuine link between a ship and the flag state, ${ }^{35}$ and to vague requirements in relation to ownership and manning of the said ship. ${ }^{36}$ For instance the now defunct provisions of Section 1 of the UK Merchant Shipping Act $1894^{37}$ relating to registration of British ships were very strict in relation to ownership requirements to the extent that for corporate bodies to become owners of a British ship it must be 'established under and subject to the laws of some part of the British dominions, and having their principal place of business in those dominions' and in relation to British born individuals who have become citizens of a foreign state, it is prescribed that they 'are not qualified unless they take the oath of allegiance and also, during the period of ownership, are resident in the British dominions or are partners in a firm carrying on business in the British dominions. ${ }^{38}$ This approach has been watered down in the current law in the UK secondary legislation largely as a result of European law implications including the right of free movement of workers. ${ }^{39}$

The strict approach adopted in the UK Merchant Shipping Act 1894 can be contrasted with registration of ships, in open registries or flags of convenience, which is largely based on a simple administrative procedure linked to the requirement that the shipowner, usually itself a legal fiction, i.e. a company or corporation, must be incorporated in that state, ${ }^{40}$ despite the vague norm specified in Article 91 of UNCLOS that 'there must exist a genuine link between the State and the ship. Furthermore, in a substantial number of cases, the link is even

34 U.N. doc. TD/RS/CONF/23, done at Geneva on Feb. 7, 1986.

35 See Article 1 (Objectives): 'For the purpose of ensuring or, as the case may be, strengthening the genuine link between a State and ships flying its flag, and in order to exercise effectively its jurisdiction and control over such ships with regard to identification and accountability of shipowners and operators as well as with regard to administrative, technical, economic and social matters, a flag State shall apply the provisions contained in this Convention.'

36 See in particular the UN Convention on Conditions for Registration of Ships, arts. 7, 8 and 9, supra, note 34. See, further, The United Nations Convention on the Registration of Inland Navigation Vessels, art. 3, Jan. 25, 1965, 964 U.N.T.S. 223.

3757 \& 58 Vict. C. 60.

38 EARL OF HALSBURY. Halsbury's Laws of England, Vol. XXVI. London: Butterworth \& Co, $1914, \S 7$.

39 See regulations 7 and 8 of the Merchant Shipping (Registration of Ships) Regulations 1993, supra note 29. Re fishing vessels see paragraph 14 of the said Statutory Instrument and Regina $v$ Secretary of State for Transport (Case C 221/89) Court of Justice of the European Communities [1992] 3 W.L.R. 288 [1992] Q.B. 680.

40 The same can be said about the registration or immatriculation of civilian aircraft under the aircraft registration system in Malta (See in particular the Aircraft Registration Act, \$6(1) (d) and 19 (Chapter 503 of the Laws of Malta). 
more tenuous and is based simply on an extremely slender relationship between the flag state and a fictitious legal person not necessarily based in the flag state, with the only requirement being the nomination by that company or corporation of an agent with residence in the flag-state. ${ }^{41}$ Despite the desirability of a normative insistence of a real link between a vessel and the flag state, the International Tribunal on the Law of the Sea (ITLOS) has stated that the need of the genuine link requirement in Article 91 of UNCLOS is 'to secure more effective implementation of the duties of the flag State, and not to establish criteria by reference to which the validity of the registration of ships of a flag State may be challenged by other States.42 This view is a continuation of the approach enunciated in the Muscat Dhows case to the effect that 'generally speaking it belongs to every Sovereign to decide to whom he will accord the right to fly his flag and to prescribe the rules governing such grants, ${ }^{33}$ and essentially as long there is the exercise of

41 See, for instance, Chapter 234 of the Laws of Malta, $\$ 4$, which provides that:

'(1) A ship shall not be eligible to be registered under this Act unless owned wholly by persons of the following description (in this Act referred to as persons qualified to own a Maltese ship), namely -

(a) citizens of Malta;

(b) bodies corporate established under and subject to the laws of Malta having their principal place of business in Malta or having a place of business in Malta and satisfying the Minister that they can and will ensure due observance of the laws of Malta relating to merchant shipping;

(c) such other persons as the Minister may, by regulations, prescribe, and, saving any other provision of this Act, if a registered ship ceases to be owned wholly by persons qualified to own a Maltese ship, such ship shall cease to be a Maltese ship.'

This provision should be read in conjunction with regulation 4 of the Ships eligible for Registration Regulations (S.L. 234.23) which provides for ownership of a Maltese vessel by an international owner (defined in paragraph 2 of the said regulations). A most tenuous of links is required between the international owner and the flag state by regulation 5 which imposes the requirement by the shipowner of having a resident agent who is habitually resident in Malta. This approach for registration of merchant vessels is substantially wider that the Maltese law counterpart in relation to aircraft registration (See S.L. 503.01, the Aircraft Registration (International Registrant) Regulations, 2010 (L. N. 537 of 2010).

42 The M/V Saiga (No. 2) (1999) 120 ILR 133, [83]. See also The M/V "Virginia G", ITLOS, Apr. 14, 2014, where it is stated at paragraph 113 that: 'In the view of the Tribunal, once a ship is registered, the flag State is required, under article 94 of the Convention, to exercise effective jurisdiction and control over that ship in order to ensure that it operates in accordance with generally accepted international regulations, procedures and practices. This is the meaning of "genuine link"'. See, further, the enforcement obligations under Article 217 of UNCLOS 1982 supra note 11.

43 Great Britain v. France, Perm. Ct. Arb. 1905, The Hague Arbitration Cases (1915), 69 at 72. See also statement by Justice Jackson (US Supreme Court) in Lauritzen v. Larsen, 345 U.S. 571 (73 S.Ct. 921,97 L.Ed. 1254) 1953. [online]. Available at: <http://www.law.cornell. edu/supremecourt/text/345/571\#fn17> Accessed: 21.11. 2013): 'Each state under international law may determine for itself the conditions on which it will grant its nationality to a merchant ship, thereby accepting responsibility for it and acquiring authority over it. Nationality is evidenced to the world by the ship's papers and its flag. The United States has firmly and successfully maintained that the regularity and validity of a registration can be 
'effective jurisdiction and control' ${ }^{44}$ by the flag state', a genuine link is de iure in existence; the dubious and questionable interpretative approach adopted in The M/V Saiga (No. 2) and later case-law ${ }^{45}$ effectively can stultify the patent purpose for which international law requires a 'genuine link'; it is difficult to argue against the requirement of a genuine link ascertainable immediately before the coming into effect of the actual registration of the specific ship, rather than its relegation to the mere formality of post-registration control, ${ }^{46}$ for instance the obligation of the flag state to require the master of the said ship to render assistance in terms of Article 98 of UNCLOS. ITLOS's approach can be characterised as evidence of the triumph of formality over substance, and can be contrasted with the more sensible approach applied in relation to the process of naturalization in the Nottebohm ${ }^{47}$ case dealt with below to the effect that: ' $[\mathrm{t}]$ hat naturalization was not based on any real prior connection with Liechtenstein, nor did it in any way alter the manner of life of the person upon whom it was conferred in exceptional circumstances of speed and accommodation... It was granted without regard to the concept of nationality adopted in international relations.'

\subsubsection{Stateless Ships \& Interdiction}

The purported right of outright seizure of a stateless ships is a highly debatable matter, and it appears that there are at least two views, that is, that such ship enjoys no protection, and the seemingly more acceptable view that 'some further jurisdictional nexus or permissive rule is required to justify seizure. ${ }^{48} \mathrm{Mey}$ ers suggests that, in the absence of a ship being reasonably suspected of being involved in the slave trade or piracy ${ }^{49}$ or if the ship is the object of the exercise of the right of hot pursuit by the coastal state, ${ }^{50}$ there are substantial limits on the

questioned only by the registering state.'

44 The $M / V$ "Virginia G", supra note 42 at $\$ 111$.

45 Similarly in The $M / V$ "Virginia G" supra note 42 , it is stated at $\$ 110$ : “The Tribunal considers that Article 91, paragraph 1, third sentence of the Convention [UNCLOS] requiring a genuine link between the flag state and the ship should not be read as establishing prerequisites or conditions to be satisfied for the exercise of the right of the flag State to grant its nationality to ships.'

46 See in particular paragraph 83 of the ITLOS judgment: ' 83 . The conclusion of the Tribunal is that the purpose of the provisions of the Convention on the need for a genuine link between a ship and its flag State is to secure more effective implementation of the duties of the flag State, and not to establish criteria by reference to which the validity of the registration of ships in a flag State may be challenged by other States.' The ITLOS came to this conclusion after reviewing the legislative history of Article 94 of UNCLOS 1982. The remedy for a State with doubts about the appropriateness (relating to 'proper jurisdiction and control') of a ship's registration is to utilise the remedy available via Article 94(6) of the said Convention providing for a lodging of a report to that effect with a flag state.

47 Nottebohm Case, supra note 5.

48 See GUILFOYLE, Douglas. Shipping Interdiction and the Law of the Sea. Cambridge: Cambridge University Press, 2009, p. 17.

49 See UNCLOS, supra note 11, art. 105.

50 Ibid., art. 111. 
rights of a state to seize or inspect a stateless vessel on the high seas. ${ }^{51}$ UNCLOS does not provide the right of universal jurisdiction in relation to a stateless vessel, although in terms of Article 110 (right of visit), the said Convention does permit a warship ${ }^{52}$ to 'proceed to verify the ship's right to fly its flag' if there is 'reasonable ground for suspecting that ...the ship is without nationality', and 'to send a boat under the command of an officer to the suspected ship' but the Convention stops short of providing a right of seizure in such case. ${ }^{53}$ Furthermore, one should not ignore the possible use of diplomatic protection by the national state of the individuals (unless they are themselves also stateless) on board a stateless ship. ${ }^{54}$ There is a jurisdiction, short of universal jurisdiction, in the case of unauthorised broadcasting from the high seas in terms of Article 109 of UNCLOS. There are further exceptional instances where a foreign ship may be intercepted on the high seas, ${ }^{55}$ including in terms of a United Nations Security Council Resolution, ${ }^{56}$ and the right of self-defence invoked under Article 51 of the United Nations Charter 1945. ${ }^{57}$

The issue of the rights of a stateless vessel has recently resurfaced to the $m v$ Enrica Lexie ${ }^{58}$ case decided by the Indian Supreme Court. It has been argued that, once the St. Antony, a twelve-metre fishing boat, ${ }^{59}$ was not registered under the Indian Merchant Shipping Act it had the status of a stateless ship at the time of the incident, where two men were killed by Italian soldiers assigned to antipiracy duties on the $m v$ Enrica Lexie. ${ }^{60}$ If the St Anthony were indeed stateless,

51 See MEYERS, supra note 16, at 309-323.

52 See further Article 110, (4) and (5).

53 See TANAKA, Yoshifumi. The International Law of the Sea. Cambridge: Cambridge University Press, 2015, p. 168.

54 See CHURCHILL, Robin R, and LOWE, Alan V. The Law of the Sea. Manchester: Manchester University Press, 1999, p. 214.

55 See supra note 51 , at 173 et seq.

56 See, for example, S.C. Res. 1718 (Oct. 14, 2006) relating to embargo on the Democratic People's Republic of Korea.

57 U.N. Charter, art. 51 states: 'Nothing in the present Charter shall impair the inherent right of individual or collective self-defence if an armed attack occurs against a Member of the United Nations, until the Security Council has taken the measures necessary to maintain international peace and security. Measures taken by Members in the exercise of this right of self-defence shall be immediately reported to the Security Council and shall not in any way affect the authority and responsibility of the Security Council under the present Charter to take at any time such action as it deems necessary in order to maintain or restore international peace and security'.

58 Supreme Court judgment. [online]. Available at: <http://www.sidi-isil.org/wp-content/ uploads/2013/03/SUPREME-COURT-OF-INDIA-18.01.2013.pdf $>$ Accessed: 3.10.2016.

59 Supreme Court judgment, para 29.

60 RONZITTI, Natalino. The Enrica Lexie Incident: Law of the Sea and Immunity of State Officials Issues. The Italian Yearbook of International Law, 2012, Vol. 22, p. 16: 'One could argue that the St Antony, while on the high seas, may be equated to a stateless vessel. Stateless vessels cannot be assimilated to the territory of any State and it does not matter if the persons on board had Indian nationality. Stateless vessels are not protected under interna- 
this argument would find comfort in the first part of the statement by the Privy Council in The Asya ${ }^{61}$ that:

Their Lordships would accept as a valid statement of the law the following passage from Oppenheim's International Law (6th ed.), vol. I., p. 546: "In the interest" of order on the open sea, a vessel not sailing under the maritime flag of a State enjoys no protection whatever, for the freedom "of navigation on the open sea is freedom for such vessels only" as sail under the flag of a State." Having no usual ship's papers which would serve to identify her, flying the Turkish flag, to which there was no evidence she had a right, hauling it down on the arrival of a boarding party and later hoisting a flag which was not the flag of any State in being, the Asya could not claim the protection of any State nor could any State claim that any principle of international law was broken by her seizure.

However, it is not very convincing to argue that registration under the Tamil $\mathrm{Nadu}$ (one of the twenty-nine states constituting India) fishing laws as a limited registration entitling the register ship to navigate only in territorial waters, would render the ship stateless outside such waters. The Indian Merchant Shipping Act 1958 makes provision for certain ships to be exempt from registration in section $22 .{ }^{62}$ Furthermore, it is undoubtedly lack of nationality rather than registration which renders a ship stateless. Via registration as a Tamil Nadu fishing vessel, and an actual and undoubtedly rigorous genuine link with India, the allocation' and 'immatriculation' ${ }^{63}$ of the vessel is undoubtedly Indian. It would seem to be very difficult, if not impossible, to argue that the St Antony was a stateless vessel, even though its claim to Indian nationality may arguably be lost for the purposes of domestic law in terms of section 22 during navigation outside territorial waters. ${ }^{64}$ It is to be noted that on 21 July 2015 Italy petitioned ITLOS to

tional law'

61 Privy Council (1948) AC 351, at 369-370. This judgment is cited by the United States Court of Appeal (in United States v. Marino-Garcia and Others, 679 F. 2d 1373, $11^{\text {th }}$ Circuit 1982, at paras. 13 et seq.). The US Court of Appeal stated that 'vessels without nationality are international pariahs. They have no internationally recognised rights to move freely on the high seas......Moreover, flagless vessels are frequently not subject to the laws of a flag-state. As such, they represent "floating sanctuaries from authority" and constitute a potential threat to the order and stability of navigation on the high seas.' (Ibid., at para. 12).

62 Act No 44 of 1958, $\$ 22$ reads as follows:

'22. Obligation to register. -

(1) Every Indian ship, unless it is a ship which does not exceed fifteen tons net and is employed solely in navigation on the coast of India, shall be registered under this Act.

(2) No ship required by sub-section (1) to be registered shall be recognised as an Indian ship unless she has been registered under this Act'.

63 This is a term used by MEYERS, supra note 51, Chapter 1.

64 Incident occurred circa 20.5 nautical miles off the coast of India (see The 'Enrica Lexie' incident (Italy v. India) (Case No. 24), Aug. 24, 2014, ITLOS Rep., $\$ 36$. 
prescribe provisional measures under Article 290(5) of UNCLOS. On 24 August 2015, the Tribunal decided as a provisional measure that 'Italy and India shall both suspend all court proceedings and shall refrain from initiating new ones which might aggravate or extend the dispute submitted to the Annex VII arbitral tribunal or might jeopardize or prejudice the carrying out of any decision which the arbitral tribunal may render. ${ }^{65}$

\subsubsection{Revocation of Nationality of a Ship}

The Maltese Merchant Shipping Act ${ }^{66}$ provides for the revocation of nationality of ships, and besides making provision for such revocation via a direction by the Registrar of Shipping (for example, where the vessel is an actual or a constructive total loss, ${ }^{67}$ or consequent to the application for deletion by the owner), also grants discretion to the relevant minister to order cessation of registration 'if it is in the national interest or in the interest of Maltese shipping. ${ }^{68} \mathrm{~A}$ similarly wide ranging but differently worded provision is contained in Section 6A(b)(ii) of the Cypriot Merchant Shipping (Registration of Ships, Sales and Mortgages) laws of 1963 to $2005 .^{69}$ In the case of British registered ships, there is no such widely discretionary right for revocation of ship nationality by the flag state, although there are specific grounds for such revocation under paragraph 56 of the Merchant Shipping (Registration of Ships) Regulations 1993. ${ }^{70}$

65 See paragraph 141 of ITLOS Order dated 24 August 2015. See further The Italian Republic v. The Republic of India, Order 29 April 2016, by Arbitral Tribunal (Perm. Ct. Arb. 2016).

66 Chapter 234 of the Laws of Malta.

67 Ibid., $\$ 29(2)$.

$68 \mathrm{Ibid}$., $\$ 29(1)$. However, such an administrative act by the relevant minister, which the author understands has been used in exceptional circumstances, would be subject to judicial review in terms of $\$ 469 \mathrm{~A}$ of the Code of Organisation and Civil Procedure (Chapter 12 of the Laws of Malta). Similarly $\$ 13$ (1) of the Aircraft Registration Act (Chapter 503 of the Laws of Malta) provides for refusal of registration or discontinuance of registration inter alia when 'in the opinion of the Minister, it would be inexpedient in the public interest for the aircraft to be or to continue to be registered in Malta' $(\$ 13(1)(\mathrm{e}))$.

69 ' 6 A. Notwithstanding the provisions of this Law or of any other law for the time being in force, the Minister shall have additional power, whenever there are reasonable grounds which satisfy him that $-\ldots$

(b) the owner or the master of a Cyprus ship or any person being in charge of any Cyprus ship

(ii) uses or permits or allows the Cyprus ship to be used in operations inconsistent with the interests of the Republic or the public interest in general ;...'

See also the Maritime Act 1990 of the Republic of the Marshall Islands, \$223, which inter alia, makes the continued validity of a vessel's Registry Certificate subject to the 'good standing of the owning entity'.

70 See para. 87 of the said statutory instrument in relation to the revocation of bareboat charter registration under the British system. 


\subsection{Nationality of Humans and its Commercialisation}

Given that the nationality of ships has been commercialised undoubtedly in part due to the approach of ITLOS to the meaning of the requirement of a 'genuine link', it comes as no surprise that a number of countries, including some ${ }^{71}$ in the European Union, have enacted legislation which some have interpreted as leading to the sale of human nationality or citizenship, while others treat it as a mechanism whereby talent can be attracted to the grantor state from foreign states. Although there are substantial similarities between nationalities of humans and ships, one substantial difference relates to duration. Unless revoked human nationality does not come to an end; on the other hand nationality of a ship is normally subject to a time-limit: in the case of British ship registration it is of five years. ${ }^{72}$ Furthermore, whereas there are statutory obligations on flag states in relation to registered ships, when it comes to humans such controls may well be minimal once nationality is granted to a person who moves out of the territorial jurisdiction of the State granting nationality.

It is a right belonging to each state to grant nationality; however there are constraints on this right. ${ }^{73}$ Article 15 of the Universal Declaration of Human Rights 1948 enshrines at soft-law level the principle that 'Everyone has the right to a nationality', and that 'no one shall be arbitrarily deprived of his nationality, nor denied the right to change his nationality'. Statelessness seems to be a state of fact which international law tries to avoid. ${ }^{74}$ In the judgment in the case Perez $v$. Brownel $7^{5}$ the right to be a citizen of a state was called 'man's basic right for it is nothing less than the right to have rights'.

\subsubsection{Sale of Human Nationality ${ }^{76}$ and its Revocation}

A recent statute emanating from the parliament of the Republic of Malta ${ }^{77}$ together with the related Individual Investor Programme of the Republic of Malta Regulations $^{78}$ has raised the issue inter alia in the Maltese press as to whether

71 Malta and Cyprus.

72 Merchant Shipping (Registration of Ships) Regulations 1993 (S.I. 1993/3138), para. 39. See para. 83 in relation to duration of British bareboat charter registration.

73 See PREUSS, Lawrence. International Law and Deprivation of Nationality', Georgetown Law Journal, Vol. 23, Issue 2, p. 250, at p. 254, where it is stated that: 'Every state possesses, in principle exclusive competence to determine the rules relative to the acquisition and loss of its nationality. This wide discretion, however, is not unlimited, but is restricted by duties arising from agreements with other states, and by the general principles of international law.

74 Ibid., at 269 et seq.

75 (1958) 356 US 44, 64, per Warren CJ.

76 See GITTLESON, Kim. Where is the cheapest place to buy citizenship? [online]. Available at $<\mathrm{http} / / / \mathrm{bbc} . c 0 . u k /$ news/business $>$. Accessed 4.6.2014.

77 The Maltese Citizenship (Amendment) Act, 2013, Act No. XV of 2013.

78 S.L. 188.03. The main general requirements are set out in para. 4(1) of said Regulations: '(1) The qualifications and general requirements for a person to be a main applicant for 
citizenship granted otherwise that via ius sanguinis, jus soli, or residence for a substantial period of time, ${ }^{79}$ can be subsequently $<$ revoked by the enactment of new legislation. ${ }^{80}$ In so far as international law is concerned, 'it is for each State to determine, through the operation of national law, who are its citizens, ${ }^{81}$ but 'this determination will be recognised at the international level so far as it complies with general principles of international law. ${ }^{32}$ This view accords with Article 1 of the 1930 Convention on Certain Questions Relating to the Conflict of Nationality Laws ${ }^{83}$ which provides that:

It is for each State to determine under its own law who are its nationals. This law shall be recognised by other States in so far as it is consistent with international conventions, international custom, and the principles of law generally recognised with regard to nationality.

While there is no doubt that an ordinary law can be substituted or deleted by a later act of Parliament, the issue posed raises human rights and international law concerns if the revocation, although prima facie exercised within national legal parameters, renders stateless the individual concerned. On this point one can refer to some notorious and thankfully long extinct laws depriving a citizen of nationality emanating from dictatorial regimes. It suffices here to mention the 1933 Nazi law providing for a process of denaturalisation in certain instances if the naturalisation is considered undesirable. ${ }^{84}$ Furthermore, Preuss refers to a New Zealand law of 1917 that gave the right to the Governor General, inter alia

citizenship under the programme shall be that any such person:

$(a)$ is at least eighteen years of age;

(b) proposes to make a contribution as determined in the Schedule;

(c) meets the application requirements;

(d) commits himself to provide proof of residence in Malta, and to provide proof of title to residential property in Malta in accordance with these regulations;

(e) commits himself to invest, amongst others, in stocks, bonds, debentures, special purpose vehicles or to make other investments as provided from time to time by Identity Malta by means of a notice in the Gazette...'

79 A number of countries operate a dubious 'economic citizenship' programme; see ANON., 'Passports to Ignominy', The Economist, Nov. 23, 2013. [online] Available at: <http://www. economist.com/news/americas/21590574>. Accessed 24.11.2013.

80 Later Regulations entitled the Individual Investors Programme of the Republic of Malta Regulations, S. L. 188.03), provide for a rather tenuous and vaguely worded residency requirement in regulation 4 specified in the Guidelines ([online] Available at: <http:// iip.gov.mt/wp-content/uploads/2014/02/Checklist-and Guidelines-4.pdf >. Accessed on 9.32016) to be a period of a minimum of 12 months preceding the date of issue of the certificate of naturalisation. Residency is then noticeably absent in regulation of these regulations in the context of the grounds for the revocation of such nationality.

81 BATCHELOR, Carol A. Statelessness and the Problem of Resolving Nationality Status. International Journal of Refugee Law, Vol. 10, No. 1/2, 1998, p. 156 at p. 156.

82 Ibid.

83 179 L.N.T.S, 89.

84 See supra note 73, at p. 250. 
on grounds of public policy, 'to withdraw the certificate of any British subject, irrespective of his nationality of origin's ${ }^{85}$

Nationality and the grant of citizenship are one of the attributes accompanying the sovereignty of a state. In the celebrated decision by the International Court of Justice in Nottenbohm ${ }^{86}$ the Court stated that 'according to the practice of States, to arbitral and judicial decisions and to the opinion of writers, nationality is a legal bond having as its basis a social fact of attachment, a genuine connection of existence, interest and sentiments, together with the existence of reciprocal rights and duties. ${ }^{87}$ The right of a state to grant citizenship through naturalisation was considered to be a serious and delicate matter:

Naturalization is not a matter to be taken lightly. To seek and to obtain it is not something that happens frequently in the life of a human being. It involves his breaking of a bond of allegiance and his establishment of a new bond of allegiance. It may have far reaching consequences and involve profound changes in the destiny of the individual who obtains it. It concerns him personally, and to consider it only from the point of view of its repercussions with regard to his property would be to misunderstand its profound significance. In order to appraise its international effect, it is impossible to disregard the circumstances in which it was conferred, the serious character which attaches to it, the real and effective, and not merely the verbal preference of the individual seeking it for the country which grants it to him.

In the context of the specific details of the Nottebohm litigation, the International Court of Justice insisted on the requirement of a genuine link between the State and the person it was seeking to protect as its national:

These facts clearly establish, on the one hand, the absence of any bond of attachment between Nottebohm and Liechtenstein and, on the other hand, the existence of a long-standing and close connection between him and Guatemala, a link which his naturalization in no way weakened. That naturalization was not based on any real prior connection with Liechtenstein, nor did it in any way alter the manner of life of the person upon whom it was conferred in exceptional circumstances of speed and accommodation. In both respects, it was lacking in the genuineness requisite to an act of such importance, if it is to be entitled to be respected by a State in the position of Guatemala. It was granted

85 Ibid., at p. 260. See also reference to a similar Australian law of 1918 at pp. 260-261.

86 Supra note 5, at p. 2. In the present case it is necessary to determine whether the naturalization conferred on Nottebohm can be successfully invoked against Guatemala, whether, as has already been stated, it can be relied upon as against that State, so that Liechtenstein is thereby entitled to exercise its protection in favour of Nottebohm against Guatemala (p.21).

87 Ibid., at 23. 
without regard to the concept of nationality adopted in international relations. ${ }^{88}$

At international law, naturalisation requires certain attributes for its validity. Reference is made in the Nottebohm judgment to Article 5 of the 1930 of the Convention relating to the Conflict of Nationality Laws providing criteria of the 'individual's genuine connections for the purpose of resolving questions of dual nationality which arise in third States': ${ }^{39}$

According to the practice of States, to arbitral and judicial decisions and to the opinions of writers, nationality is a legal bond having as its basis a social fact of attachment, a genuine connection of existence, interests and sentiments, together with the of reciprocal rights and duties. It may be said to constitute the juridical expression of the fact that the individual upon whom it is conferred, either directly by the law or as the result of an act of the authorities, is in fact more closely connected with the population of the State conferring nationality than with that of any other State. Conferred by a State, it only entitles that State to exercise protection vis-à-vis another State, if it constitutes a translation into juridical terms of the individual's connection with the State which has made him its national. ${ }^{90}$

The European Convention on Nationality ${ }^{91}$ defines 'nationality' as 'the legal bond between a person and a State' and proclaims that 'a. everyone has a right to nationality; b. statelessness shall be avoided; $c$. no one shall be arbitrarily deprived of his or her nationality; $d$. neither marriage nor the dissolution of a marriage between a national of a State Party and an alien, nor the change of nationality by one of the spouses during marriage, shall automatically affect the nationality of the other spouse.'

\subsubsection{Revocation of Human Nationality and the Avoidance of Statelessness}

The grant and possible revocation of citizenship are dealt with at both international and domestic law. In international law, one issue relates to revocation of citizenship in time of strife, civil war or war between two and more states, a matter which could have humanitarian implications. Undoubtedly, there is less moral objection to revocation of nationality where there is no genuine link between the grantor state and its naturalised citizen. Indeed the genuine link mechanism has been touted as an effective mechanism to the statelessness problem. ${ }^{92}$

88 Ibid., at 26.

89 Ibid., p. 23.

90 Ibid., p. 23.

91 E.T.S. No 166.

92 See WEISSBRODT, David and COLLINS, Clay. The Human Rights of Stateless Persons. Human Rights Quarterly, Vol. 28, 2006, p. 245, at p. 276. 
The judgment by the UK Supreme Court in Al-Jedda referred to below, considers in paragraph 12 the evil of statelessness and the notorious Reich Citizenship Law of 15 September 1935 which stripped Jewish individuals of their German citizenship. Such arbitrary revocation, normally associated with fascist or other dictatorial regimes, particularly if based on racial or similar attributes, would undoubtedly constitute an abus de $d r o i t^{93}$ and should be struck down accordingly.

In this Supreme Court judgment, reference is also made to the soft law provision contained in the Universal Declaration of Human Rights 1948 which provides in Article 14 that 'everyone has the right to a nationality, and that 'no one shall be arbitrarily deprived of his nationality nor denied the right to change his nationality'. Furthermore reference is made in the judgment to the statement of Warren CJ in Perez v. Brownell94 that the right to a nationality is a 'man's basic right, for it is nothing than the right to have rights', and also ${ }^{95}$ to the European Convention on Nationality 1997 which, whilst providing for seven instances of revocation of citizenship, disallows such revocation in six of such instances where this would cause statelessness, except where nationality had been obtained by misrepresentation or fraud. ${ }^{96}$ The Supreme Court made reference to the judgment of the European Court of Human Rights (ECtHR) in Karassev $v$ Finland, ${ }^{97}$ where the court had stated that: 'Although right to a citizenship is not as such guaranteed by the Convention or its Protocols (cf. No. 11278/84, Dec. 1 July 1985, D.R. 43, pp. 216 at 220), the Court does not exclude that an arbitrary denial of a citizenship might in certain circumstances raise an issue under Article 8 of the Convention because of the impact of such a denial on the private life of the individual.' In that case the ECtHR dealt with a claim by an individual that the Finnish authorities had refused to recognise as a Finnish citizen. However, the application was rejected as the evidence pointed to the fact that when the applicant was born, he did have a right to Finnish citizenship. The court did not find that there was a breach of Article 8 of the European Convention. Furthermore the applicant and his family had not been refused an alien passport or other social benefits. Furthermore the Court found that there had not been a breach of Article 14 of the Convention. On the basis of this case, it would appear that if a state does not recognise or withdraws citizenship to a person with access to another citizenship, without infringing their private or family life, there would not be a breach of the European Convention on Human Rights (ECHR). Despite its limitations, and despite not accepting that the right to nationality is an inherent human right, the Strasbourg Court recognises the human rights implications of withdrawal of citizenship, thereby acknowledging that the powers of a state in

93 PREUSS, supra note 73, at pp. 250-276.

94 (1958) 356 US 44, 64.

95 Al-Jedda, UK Supreme Court 2013 at para. 21.

96 Ibid., $\$ 7$.

97 (1999) 28 E.H.R.R. C.D. 312. 
relation to nationality and citizenship are not unlimited. This judgment can be compared to the more outright statement contained in an advisory opinion of the American Court of Human Rights in Re Amendments to the Naturalization Provisions of the Constitution of Costa Rica, ${ }^{98}$ which goes as far as proclaiming the general acceptance of nationality as 'an inherent right of all human beings.99

Minimum standards of treatment of stateless persons are addressed in the 1954 Convention relating to the Status of Stateless Persons. ${ }^{100}$ The UN Convention on the Reduction of Statelessness 1961, ${ }^{101}$ Article 8(1), provides the general principle that 'a Contracting State shall not deprive a person of its nationality if such deprivation would render him stateless'; this general principle is subject to exceptions, specified in Articles 7 and 8(2) thereof.

Revocation of citizenship obtained by naturalisation has been an issue addressed recently by the UK Supreme Court in Al-Jedda $v$ Secretary of State for the Home Department (Open Society Justice Initiative intervening) ${ }^{102}$ where the Supreme Court overruled a decision by the Secretary of State to withdraw citizenship. The issue dealt with by the Supreme Court related specifically to section 40 of the amended British Nationality Act $1981^{103}$ which in sub-section (4) provides that 'the Secretary of State may not make an order under subsection (2) [depriving a person of citizenship status on the grounds that this is conducive to the public good] if he is satisfied that the order would make a person stateless'. The Supreme Court refuted the assertion by the Secretary of State that a purposive interpretation should be applied to the effect that, where there were grounds for an order for revocation of citizenship, she should not be disabled from revoking it 'in circumstances in which it remains open to the person so easily and so immediately to avoid becoming stateless.. ${ }^{104}$ The UK Supreme Court reached this

98 Advisory opinion dated 19 January 1984, OC-4/84, as cited in CHAN, Johannes M.M. The Right to Nationality as a Human Right - The Current Trend Towards Recognition. Human Rights Law Journal, Vol. 12, No. 1-2, 1991, p. 1 at pp. 5-6.

99 'It is generally accepted today that nationality is an inherent right of all human beings. Not only is nationality the basic requirement for the exercise of political rights. It also has an important bearing on the individual's legal capacity. Thus, despite the fact that it is traditionally accepted that the conferral and regulation of nationality are matters for each State to decide, contemporary developments indicate that international law does impose certain limits on the broad powers enjoyed by the States in that area, and that the manner in which States regulate matters bearing on nationality cannot today be deemed within their sole jurisdiction; those powers of the State are also circumscribed by their obligations to ensure the full protection of human rights.

The classical doctrinal position, which viewed nationality as an attribute granted by the State to its subjects, has gradually evolved to the point that nationality is today perceived as involving the jurisdiction of the State as well as human rights issues.'

100360 U.N.T.S. 117.

101989 U.N.T.S. 175.

1029 October 2013 [2013] UKSC 62; [2013] 3 W.L.R. 1006.

1031981 c. 61.

104 Ibid., $\$ 31$. 
view despite the fact that counsel for the Secretary of State restricted this argument 'to the re-acquisition of a former nationality as opposed to the acquisition of a fresh nationality. ${ }^{105}$ The response of the Home Secretary has been to propose an amendment to the legislation whereby in the case of persons whose conduct seriously prejudices UK interests they could be 'stripped of their passports', presumably thus referring to denaturalisation, even if this has the effect of rendering them stateless, ${ }^{106}$ although it is possible to envisage a situation where a passport is withdrawn via the use of the Royal Prerogative without revocation of nationality, an idea recently floated by the UK Government as a mechanism of dealing with British nationals returning to the UK after fighting for ISIL in Iraq and Syria. ${ }^{107}$ The Al-Jedda case resurfaced before the Special Immigration Appeals Commission in Al-Jedda $v$ Secretary of State for the Home Department which on 18 July 2014 accepted that Al-Jedda had not been rendered stateless by a deprivation order, and determined that a deprivation order made under the British Nationality Act 1981 was not preceded by a duty to consult. ${ }^{108}$

Furthermore, there is the issue as to whether the revocation of the citizenship (by naturalisation) of a member state of the European Union, ${ }^{109}$ has the effect of revoking European citizenship. In this respect, one can refer to Article 8 inserted by the Treaty on European Union ${ }^{110}$ into the EC Treaty. This provides that: '1. Every person holding the nationality of a Member State shall be a citizen of the

105 Ibid., paragraphs 31-32.

106 See 'May intends to strip British terror suspects of passports'. The Times, 12.11.2013 at p. 2. See further Regina (XH and Another) $v$ Secretary of State for the Home Department [2016] EWHC 1808 (Admin], July 28, 2016.

107 See ANON., 'New power to confiscate terror suspects' passports'. [online] Available at: $<$ http://www.bbc.co.uk/news/uk-22297436>. Accessed: 16.9.2014. Revocation of a passport can have very harsh implications for the individual concerned, as s/he would be deprived of travel documentation which a 'refugee' would normally be entitled to under Article 28 of the United Nations Convention relating to the status of Refugees 1951 (189 U.N.T.S. 137). See also the Article 1 of the same convention relating to the definition of refugee.

108 See WESTLAW, 'Case Abstract'. [online]. Available at: http://login.westlaw.co.uk.plymouth.idm.oclc.org/maf/wluk/app/document?\&srguid=ia744d0650000014e1ff1a8d5481c4 6a5\&docguid=I0638F08016A411E49807B760CB11C2CE\&hitguid=I0638F08016A411E4 9807B760CB11C2CE\&rank=1\&spos $=1 \&$ epos $=1 \& \mathrm{td}=351 \&$ crumb-action $=$ append $\&$ conte $\mathrm{xt}=12 \&$ resolvein $=$ true $>$. Accessed: 23.6.2015.

109 See, further, VAN EIJKEN, Hanneke. European Citizenship and the Competence of member States to Grant and to Withdraw the Nationality of their Nationals. Merkourios, Case Note, Vol. 27, Issue 72, 2010, at pp. 65-69. In the case of Rottmann v Freistaat Bayern, the Grand Chamber of the European Court of Justice decided that '[i]t is not contrary to European Union law, in particular to Article 17 EC, for a Member State to withdraw from a citizen of the Union the nationality of that State acquired by naturalisation when that nationality was obtained by deception, on condition that the decision to withdraw observes the principle of proportionality. Case C-135/08 ECJ (Grand Chamber) 2 March 2010.

110 OJ C 326, 26.10.2012, pp. 13-390. 
Union. 2. Citizens of the Union shall enjoy the rights conferred by this Treaty and shall be subject to the duties imposed thereby." This has led to the view that 'a denationalised person would be a Union citizen in a member State of which he was not a national.'111

\section{Conclusion}

Nationality of ships and of humans has in some legal systems moved away from the requirement of a pre-existing genuine link to one where nationality is a commodity which is available for a consideration. Whereas it may be understandable that, on the basis of ethical considerations, a pre-existing genuine link could be treated as less contentious consideration in the case of a ship than in the case of a human, there is no doubt that effective control (the basis of the genuine link notion as interpreted in The Saiga No. 2 and post-Saiga), is undoubtedly more necessary in the case of a ship which may be outside the jurisdiction of any State than in the case of a human. The success of port state control ${ }^{112}$ as distinct from the patchy implementation of flag-state control ${ }^{113}$ coupled with the Saiga No 2 approach is consistent with the view that nationality of ships is not necessarily based on a genuine link but can be a mere administrative exercise where nationality may be bought and sold. As indicated above, there is at least some patchy state practice that nationality of humans is moving towards a similar administrative scenario. Revocation of nationality of ships is very unlikely to raise human rights considerations other than those based on Article 1 of Protocol No. 1 of the European Convention or a similar norm in a legal system in a State which is not a party to that Convention.

If a state revokes nationality which had been acquired on a cash for passport basis without the requisites provided for in international law, it would appear that that state has substantial leeway at international law, provided that that person has a right to revert to another nationality, and provided that at the time of revocation that person has not sanitised his acquired nationality by the creation of a Nottebohm genuine link. In the case of a passport for cash the transaction may arguably be treated as having 'essentially the nature of contract ${ }^{114}$ and

111 HALL, Stephen. Loss of Union citizenship in breach of human rights. European Law Review, 1996, p. 129 at p. 143.

112 See, for instance: Paris MOU, Port State Control, Annual report 2014. [online] Available at: <https://www.parismou.org>. Accessed: 3.10.2016; Directive 2009/16/EC of the European Parliament and of the Council of 23 April 2009 on Port State Control [2009] OJ L131/57; Directive 2013/38 (EU); Commission Regulation (ERU) 428/2010; Commission Regulation (EU) No. 801/2010; Commission Regulation (EU) 1205/2012.

113 See, in particular, HAYASHI, Moritaka. Toward the Elimination of Substandard Shipping: The Report of the International Commission on Shipping. The International Journal of Marine and Coastal Law, Vol. 16, No. 3, p. 501, at pp. 506-507.

114 PREUSS, supra note 73, at 263; SAWYER, Caroline. Civis Britannicus sum' no longer? Deprivation of British nationality. Journal of Immigration Asylum and Nationality Law, 2013, p. 23 at p. 25. 
should be treated as such rather than as one of revocation of nationality. In line with Article 7 (1) of the European Convention on Nationality 1997, a State party to that Convention may well provide for the loss of nationality in the case of a 'lack of a genuine link between the State Party and a national habitually residing abroad'; this power however is not available where 'the person concerned would thereby become stateless ${ }^{\prime 115}$ or where the Convention is not part of municipal law. The convention however does not address the issue raised in the Al-Jedda case in the UK as to the legal position where statelessness follows revocation of nationality but another nationality, possibly based on jus sanguinis or jus soli, is available to the person in question. Furthermore, if a state grants nationality of convenience but then changes heart and revokes it, the expulsion of such an individual if rendered stateless, may involve the infringement of the rights of the state to which the person is expelled. ${ }^{116}$

Furthermore the right to a private and family life under Article 8 of the ECHR may give rise to a right of action by the aggrieved person, but this may well be avoided by the sort of precautions taken by Finland in the Karassev case. Obviously a revocation of a right of a cash for passport type citizenship may well give a right to the aggrieved party to invoke the provisions of Article 1 Protocol 1 of the ECHR if he/she is not adequately compensated for the revocation.

\section{References (alphabetical order)}

BATCHELOR, Carol A. Statelessness and the Problem of Resolving Nationality Status. International Journal of Refugee Law, Vol. 10, No. 1/2, 1998, p. 156.

BROWN, Edward D. The International Law of the Sea, Volume 1: Introductory Manual. Aldershot: Dartmouth Publishing Company Limited, 1994.

CHAN, Johannes M.M. The Right to Nationality as a Human Right - The Current Trend Towards Recognition. Human Rights Law Journal, Vol. 12, No. 1-2, 1991, p. 1.

CHURCHILL, Robin R, and LOWE, Alan V. The Law of the Sea. Manchester: Manchester University Press, 1999.

COGLIATI-BANTZ, Vincent P. Means of Transportation and Registration of Nationality. Abingdon, Oxon.; New York, NY: Routledge, 2015.

COLES, Richard M.F., And WATT, Edward. Ship Registration: Law and Practice. London: Informa, 2009.

EARL OF HALSBURY. Halsbury's Laws of England, Vol. XXVI. London: Butterworth \& Co, 1914.

GUILFOYLE, Douglas. Shipping Interdiction and the Law of the Sea. Cambridge: Cambridge University Press, 2009.

HALL, Stephen. Loss of Union citizenship in breach of human rights. European Law Review, 1996, p. 129.

HAYASHI, Moritaka. Toward the Elimination of Substandard Shipping: The Report of the International Commission on Shipping. The International Journal of Marine and Coastal Law, Vol. 16, No. 3, p. 501.

115 European Convention on Nationality, supra note $91, \S 7(1)$ (g), and 7(3).

116 PREUSS, supra note 73 , at p. 272 et seq. 
MANDARAKA-SHEPPARD, Aleka. Modern Maritime Law and Risk Management. London: Routledge-Cavendish, 2007, second edition.

MEYERS, Herman. The Nationality of Ships. Den Haag: Martinus Nijhoff, 1967.

ODUNTAN, Gbenga. Sovereignty and Jurisdiction in the Airspace and Outer Space. London: Routledge, 2012.

PREUSS, Lawrence. International Law and Deprivation of Nationality', Georgetown Law Journal, Vol. 23, Issue 2, p. 250.

PRICE, Griffith. The Law of Maritime Liens. London: Sweet \& Maxwell, 1940

READY, Nigel. P. Nationality, Registration and Ownership of Ships. In FITZMAURICE, Malgosia, MARTÍNEZ GUTIÉRREZ, Norman, ARROYO, Ignacio, and BELJA, Elda (eds). The IMLI Manual of International Maritime Law, Volume 2: Shipping Law. Oxford: Oxford University Press, 2016, p. 25.

RONZITTI, Natalino. The Enrica Lexie Incident: Law of the Sea and Immunity of State Officials Issues. The Italian Yearbook of International Law, 2012, Vol. 22, p. 16.

SAWYER, Caroline. Civis Britannicus sum' no longer? Deprivation of British nationality. Journal of Immigration Asylum and Nationality Law, 2013, p. 23.

SCHOENBAUM, Thomas J. Admiralty and Maritime Law. St. Paul, Minn.: West Group, 2001.

TANAKA, Yoshifumi. The International Law of the Sea. Cambridge: Cambridge University Press, 2015, p. 168.

VAN EIJKEN, Hanneke. European Citizenship and the Competence of member States to Grant and to Withdraw the Nationality of their Nationals. Merkourios, Case Note, Vol. 27, Issue 72, 2010, at p. 65.

WEISSBRODT, David and COLLINS, Clay. The Human Rights of Stateless Persons. Human Rights Quarterly, Vol. 28, 2006, p. 245.

\section{Online References}

ANON., 'New power to confiscate terror suspects' passports'. [online] Available at: $<$ http:// www.bbc.co.uk/news/uk-22297436>. Accessed: 16.9.2014.

ANON., 'Passports to Ignominy', The Economist, Nov. 23, 2013. [online] Available at: $<$ http://www.economist.com/news/americas/21590574>. Accessed 24.11.2013.

Individual Investors Programme of the Republic of Malta Regulations, S. L. 188.03, Checklist and Guidelines. [online] Available at: <http://iip.gov.mt/wp-content/ uploads/2014/02/Checklist-and Guidelines-4.pdf>. Accessed on 9.32016

GITTLESON, Kim. Where is the cheapest place to buy citizenship? [online]. Available at $<$ http://bbc.co.uk/news/business >. Accessed 4.6.2014.

PARIS MOU, Port State Control, Annual report 2014. [online] Available at: <https://www. parismou.org $>$. Accessed: 3.10.2016.

WESTLAW, 'Case Abstract'. [online]. Available at: <http://login.westlaw.co.uk.plymouth. $\mathrm{idm}$.oclc.org/maf/wluk/app/document?\&srguid=ia744d0650000014e1ff1a8d5481c4 6a5\&docguid=I0638F08016A411E49807B760CB11C2CE\&hitguid=I0638F08016A4 $11 \mathrm{E} 49807 \mathrm{~B} 760 \mathrm{CB} 11 \mathrm{C} 2 \mathrm{CE} \& \mathrm{rank}=1 \&$ spos $=1 \&$ epos $=1 \& \mathrm{td}=351 \& \mathrm{crumb}$-action=appe nd\&context=12\&resolvein=true $>$. Accessed: 23.6.2015. 